DEPARTMENT OF THE INTERIOR

UNITED STATES GEOLOGICAL SURVEY

PREPARED IN COOPERATION WITH THE

STATE OF CONNECTICUT

GEOLOGICAL AND NATURAL HISTORY SURVEY

\title{
AEROMAGNETIC MAP OF THE HARTFORD SOUTH QUADRANGIE, AND PART OF THE HARTFORD NORTH QUADRANGLE, HARTFORD AND MIDDLESEX COUNTIES, CONNECTICUT
}

GEOPHYSICAL INVESTIGATIONS

MAP GP- 847

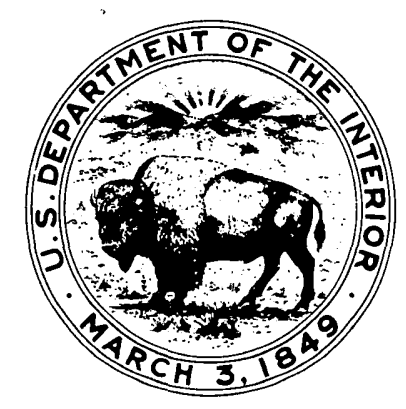

